International Journal of Engineering \& Technology, $7(4.34)(2018) 267-269$
SPC
Website: $w w w . s c i e n c e p u b c o . c o m / i n d e x . p h p / I J E T$
Research pa

\title{
Determinants of Cumulative GPA of First Year Widyatama University Students
}

\author{
Farida Nursjanti*, Indra Taruna, Shinta \\ Faculty of Business and Management, Widyatama University, Bandung, Indonesia \\ *Corresponding author E-mail: farida.nursyanti@widyatama.ac.id
}

\begin{abstract}
As a private college-oriented quality, Widyatama University has some quality commitments including receiving potential prospective students and giving priority to customer satisfaction. However, the university only uses entrance exam score, does not use previous academic performance such as national exam score to select potential prospective students. The aims of this research were to examine and to evaluate the factors which affect students' First Year Cumulative GPA (FYCGPA) in Widyatama University. This research also investigated the determinants of students' FYCGPA by the factors to explain variances in FYCGPA. This research used gender, major in high school, national exam score and entrance exam score as independent variables. Stepwise multiple regression analysis was carried out in this study. The result indicated that gender, entrance exam score, and major in high school have significant effect to FYCGPA. The model used in this study showed that $24.6 \%$ of the variances in FYCGPA can be explained by gender, entrance exam score, and major in high school. This results show that Widyatama University should consider more factors in selecting potential prospective students and providing services to first year students.
\end{abstract}

Keywords: national exam score; entrance exam score; major in high school; gender; first year cumulative.

\section{Introduction}

First year at university is important transition period for new students. They need to adapt to new education system and environment. Whereas, other students could not follow the changes of academic, social and other challenges. The transition from High School education to higher education is often experienced as challenging by students [5]. The earlier, the university recognized the risk of dropped out students, the better services the university would afford to assist study of the students [3]. His study also concluded that an important measure to evaluate the survive study of the students was first year cumulative GPA.

In [4] stated that characteristics of prospective students could be used to predict their first year cumulative GPA. Furthermore, it could be also used to identify the students with the risk of low GPA [2]. In [6, 8] also concluded that entrance exam score could affect GPA. Other factors are revealed by several researchers. In $[4,7]$ concluded that academic performance at senior high school had correlation to students' GPA. In [3] investigating the students' profile at first year, stated that gender and type of school had correlation to students' GPA.

Widyatama University has some quality commitments including receiving potential prospective students, motivating the students to be active and creative, providing sufficient facilities of study, and giving administration service to satisfy the customer, cooperating with external parties, selecting qualified teaching staff, providing dynamic curriculum matching to the development of industry and technology, giving priority to customers' satisfaction in the respect of its vision, mission and quality policy and quality objectives (www.widyatama.ac.id). In receiving the prospective students, Widyatama University performs USM (university entrance exam). Widyatama University receives prospective students only based on the result of USM scores and has not concerned to other factors. By good system, it is expected able to produce good performance graduates. However, if the selection process is insufficient with the standard, there may be students with low GPA. Based on data from Academic Division, there were more than $15 \%$ students of Study Program of Management achieving GPA less than 2.00. Most of students with under standard GPA could be problem in gaining one of quality objectives of Widyatama University that is at least $75 \%$ students able to graduate on time with satisfying performance (minimum GPA is 2.75). Gaining the quality objectives within the last two years shows that the percentage of punctual graduates with satisfying performance only reaches $62.5 \%$ (www.widyatama.ac.id). The aim of this research is to examine determinants of students' First Year Cumulative GPA (FYCGPA) in Widyatama University. Result of this study may allow Widyatama University to make more informed decisions when selecting new students and to improve the assistances to first year students.

\section{Methodology}

Applying purposive sampling, 400 participants of first year students enrolled to Widyatama University Faculty of Economics and to Faculty of Business and Management have been chosen as the sample of this research.

\subsection{The variables}

First Year Cumulative GPA (FYCGPA): The numerical average of all the students' grade achieved during the first year of study at an institution. 
- $\quad$ National Exam Score (National ES): The score achieved by students at National Exam at high school. The score is cumulative score of six subjects, both Science and Social majors. The highest score is 10 . This score is considered as representatives of academic performance at high school as it has been standardized.

- $\quad$ Entrance Exam Score (Entrance ES): The score achieved by the students when they followed USM (Entrance Exam) at Widyatama University.

- Major in High School (Major iHS): In this research, the investigated students are only from Science or Social majors as the number of students from other major are minority.

- Major in University (Major iU): In this research, the participants are from two departments at Widyatama University, those are Management and Accounting, as the majority of students at Widyatama University are from those departments. Other used variable is gender.

\subsection{Analysis}

Analysis of the sample data included descriptive, correlation, and multiple regression analysis. All analysis conducted using SPSS
15.0. Stepwise multiple regressions are used to investigate the determinants of students' FYCGPA and the percentage of variances in FYCGPA can be explained by all independent variables. This study has some limitations. First limitation, this research is limited to students in two majors: Management and Accounting. This research could be developed by involving participants from all major or students from other universities. Second limitation, this research just involves the participants of general high school graduates and out of graduates of vocational high school. Other limitation, this research uncovers other variables such as students' motivation and economic background of students' parents.

\section{Results and discussion}

To examine factors affecting students' FYCGPA, all independent variables were analyzed separately to examine their independent influence on FYCGPA. Table 1 indicates that correlation between Gender, Entrance ES, and Major in HS and FYCGPA partially was significant at 0.01 level (1-tailed).

Table 1: Correlations

\begin{tabular}{|c|c|c|c|c|c|c|}
\hline & & Major_iU & Gender & Major_iHS & FYCGPA & Entrance_ES \\
\hline \multirow[t]{3}{*}{ Major_iU } & Pearson Correlation & 1 & -.054 & $.100(*)$ & -.030 & -.071 \\
\hline & Sig. (1-tailed) & & .141 & .022 & .276 & .078 \\
\hline & $\mathrm{N}$ & 400 & 400 & 400 & 400 & 400 \\
\hline \multirow[t]{3}{*}{ Gender } & Pearson Correlation & -.054 & 1 & $-.187(* *)$ & $.331(* *)$ & $-.091(*)$ \\
\hline & Sig. (1-tailed) & .141 & & .000 & .000 & .034 \\
\hline & $\mathrm{N}$ & 400 & 400 & 400 & 400 & 400 \\
\hline \multirow[t]{3}{*}{ Major_iHS } & Pearson Correlation & $.100(*)$ & $-.187(* *)$ & 1 & $-.329(* *)$ & $-.135(* *)$ \\
\hline & Sig. (1-tailed) & .022 & .000 & & .000 & .003 \\
\hline & $\mathrm{N}$ & 400 & 400 & 400 & 400 & 400 \\
\hline \multirow[t]{3}{*}{ FYCGPA } & Pearson Correlation & -.030 & $.331(* *)$ & $-.329(* *)$ & 1 & $.258(* *)$ \\
\hline & Sig. (1-tailed) & .276 & .000 & .000 & & .000 \\
\hline & $\mathrm{N}$ & 400 & 400 & 400 & 400 & 400 \\
\hline \multirow[t]{3}{*}{ Entrance_ES } & Pearson Correlation & -.071 & $-.091(*)$ & $-.135(* *)$ & $.258(* *)$ & 1 \\
\hline & Sig. (1-tailed) & .078 & .034 & .003 & .000 & \\
\hline & $\mathrm{N}$ & 400 & 400 & 400 & 400 & 400 \\
\hline
\end{tabular}

*Correlation is significant at the 0.05 level (1-tailed).

**Correlation is significant at the 0.01 level (1-tailed).

Major in University is negatively related to First Year GPA, indicating that Management students are less academically successful in their first year at university compared to Accounting students. Major in High School has negative correlation with First Year GPA show that students with Social Major in High School have lower First Year GPA compared to students with Science Major in High School. Entrance Exam Score is positively related to First Year GPA indicate that a higher Entrance Exam Score is associated with greater First Year GPA.

Table 2: Coefficients

\begin{tabular}{|c|c|c|c|c|c|c|}
\hline & & \multirow{2}{*}{\multicolumn{2}{|c|}{ Unstandardized Coefficients }} & & & \\
\hline \multirow[b]{2}{*}{ Model } & & & & \multirow{2}{*}{$\begin{array}{c}\text { Standardized } \\
\text { Coefficients } \\
\text { Beta }\end{array}$} & \multirow{2}{*}{$\frac{\mathrm{t}}{\mathrm{B}}$} & \multirow{2}{*}{$\begin{array}{c}\text { Sig. } \\
\text { Std. Error }\end{array}$} \\
\hline & & $\mathrm{B}$ & Std. Error & & & \\
\hline \multirow[t]{2}{*}{1} & (Constant) & 2.025 & .092 & & 21.968 & .000 \\
\hline & Gender & .398 & .057 & .331 & 6.995 & .000 \\
\hline \multirow[t]{3}{*}{2} & (Constant) & .803 & .209 & & 3.835 & .000 \\
\hline & Gender & .430 & .054 & .357 & 7.896 & .000 \\
\hline & Entrance_ES & .027 & .004 & .291 & 6.426 & .000 \\
\hline \multirow[t]{4}{*}{3} & (Constant) & 1.493 & .241 & & 6.186 & .000 \\
\hline & Gender & .372 & .054 & .310 & 6.924 & .000 \\
\hline & Entrance_ES & .023 & .004 & .255 & 5.739 & .000 \\
\hline & Major_iHS & -.288 & 055 & -.237 & -5.267 & .000 \\
\hline
\end{tabular}

a. Dependent variable: FYCGPA

Table 3: ANOVA

\begin{tabular}{|c|c|c|c|c|c|c|}
\hline Model & & Sum of Squares & df & Mean Square & $\mathrm{F}$ & Sig. \\
\hline \multirow[t]{3}{*}{1} & Regression & 15.712 & 1 & 15.712 & 48.931 & $.000(\mathrm{a})$ \\
\hline & Residual & 127.799 & 398 & .321 & & \\
\hline & Total & 143.511 & 399 & & & \\
\hline \multirow[t]{3}{*}{2} & Regression & 27.752 & 2 & 13.876 & 47.588 & $.000(\mathrm{~b})$ \\
\hline & Residual & 115.759 & 397 & .292 & & \\
\hline & Total & 143.511 & 399 & & & \\
\hline \multirow[t]{2}{*}{3} & Regression & 35.331 & 3 & 11.777 & 43.110 & $.000(\mathrm{c})$ \\
\hline & Residual & 108.181 & 396 & .273 & & \\
\hline
\end{tabular}


a. Predictors: (Constant), Gender

b. Predictors: (Constant), Gender, Entrance_ES

c. Predictors: (Constant), Gender, Entrance_ES, Major_iHS

d. Dependent variable: FYCGPA

Table 2 and Table 3 show the results of stepwise multiple regression analysis. It indicated that Gender, Entrance Exam Score, and Major in High School were important factors which affect students' FYCGPA.

Variables of gender are significant toward FYCGPA supporting the research result of [3].

Entrance Exam Score has positive influence toward FYCGPA. This supports the results of [7], yet it is not along with the research conducted by [1]. The result also shows that major in high school is important factor for students' FYCGPA.

Table 4: Model summary

\begin{tabular}{|c|c|c|c|c|}
\hline Model & $\mathrm{R}$ & $\begin{array}{c}\mathrm{R} \\
\text { Square }\end{array}$ & $\begin{array}{c}\text { Adjusted R } \\
\text { Square }\end{array}$ & $\begin{array}{c}\text { Std. Error of the Esti- } \\
\text { mate }\end{array}$ \\
\hline 1 & $.331(\mathrm{a})$ & .109 & .107 & .56666 \\
\hline 2 & $.440(\mathrm{~b})$ & .193 & .189 & .53999 \\
\hline 3 & $.496(\mathrm{c})$ & .246 & .240 & .52267 \\
\hline
\end{tabular}

a. Predictors: (Constant), Gender

b. Predictors: (Constant), Gender, Entrance_ES

c. Predictors: (Constant), Gender, Entrance_ES, Major_iHS

The model used in this study showed that $24.6 \%$ of the variances in FYCGPA can be explained by gender, entrance exam score, and major in high school (as shown in Table 4).

\section{Conclusion}

The result indicates that Gender, National Exam Score, Entrance Exam Score, and Major in High School have influence on students' First Year Cumulative GPA (FYCGPA). Entrance Exam Score has positive influence toward FYCGPA, this supports the results of [7], yet it is not along with the research conducted by [1]. Variables of gender are significant toward FYCGPA supporting the research result of [3]. The result also shows that entrance exam score and major in high school are important factors for both female and male students' FYCGPA. The model used in this study shows that $25.6 \%$ of the variances in FYCGPA can be explained by gender, entrance exam score, and major in high school. In spite of these limitations, this study has important practical implications. Widyatama University should consider more factors in selecting potential students, such as students' National Exam Score and student's major in high school, performance and major in high school background to identify students who need assistances.

\section{References}

[1] Olani, A. (2009). Predicting first year university students academic success. Electronic Journal of Research in Educational Psychology, 7(3), 1053-1072.

[2] Curtis, D. A., Lind, S. L., Plesh, O., \& Finzen, F. C. (2007). Correlation of admissions criteria with academic performance in dental students. Journal of Dental Education, 71(10), 1314-1321.

[3] González-Barreto, D. R., \& González-Quevedo, A. A. (2005). Student profile of the incoming First Year Class of the College of Engineering at UPRM and their academic performance after their first year. Proceedings of the American Society for Engineering Education Annual Conference and Exposition, pp. 1-9.

[4] Green, R. J., \& Kimbrough, S. (2008). Honors admissions criteria: How important are standardized tests? http://digitalcommons.unl.edu/nchc journal/69.

[5] Gale, T., \& Parker, S. (2014). Navigating change: A typology of student transition in higher education. Studies in Higher Education, 39, 734-753.

[6] Purdie, J. R., \& Rosser, V. J. (2011). Examining the academic performance and retention of first-year students in living-learning communities and first-year experience courses. College Student Affairs Journal, 29(2), 95-1122.
[7] McCall, K. L., MacLaughlin, E. J., Fike, D. S., \& Ruiz, B. (2007) Preadmission predictors of PharmD graduates' performance on the NAPLEX. American Journal of Pharmaceutical Education, 71(1), $1-7$.

[8] Shivpuri, S., Schmitt, N., Oswald, F. L., \& Kim, B. H. (2006). Individual differences in academic growth: Do they exist, and can we predict them? Journal of College Student Development, 47(1), 6986. 